\title{
The US Factor in India-Vietnam Relationship
}

\author{
Dr. Sanghamitra Sarma \\ Research Fellow, Indian Council of World Affairs, India
}

\begin{abstract}
India enjoys very close and robust relations with Vietnam. As partners in the pursuit of common goals, both the countries have a strong stake in the prosperity of the other, especially in the Asian century. The relationship has strengthened significantly since the 1990s following India's economic liberalization and end of the cold war. The two countries enjoy an extensive economic, defence and strategic relationship that have recently blossomed into a comprehensive strategic partnership. The objective of the paper is to examine the different areas of convergence between India and Vietnam in the $21^{\text {st }}$ century and the role that the US can play in advancing the strategic relation between the two countries. The US can be seen as a vital link bringing India and Vietnam closer, particularly in the context of the significance which it has attached to the Asia-Pacific region in the $21^{\text {st }}$ century. The US factor in driving cooperation between India and Vietnam has been perceived as one which contributes towards building overall regional growth and development. Moreover, the creation of positive linkages around common interests of the three countries can foster strong and sustainable growth beneficial to the interests of the stakeholders.
\end{abstract}

Keywords: India, Vietnam, US, Cooperation, Regional development.

\section{INTRODUCTION}

Based on common civilisational and cultural ties, India and Vietnam have shared sincere bonds of friendship and mutual trust that have been continuously evolving to the level of qualitatively new boundaries. The legacy of the relationship has its roots in the common struggle for liberation from foreign rule and the national struggle for independence. In the changing regional and global political scenario, India and Vietnam are of considerable significance in the Asia-Pacific century. As strategic partners, both the countries have made undeniable strides in their relationship over the years, which, however, have more potential for growth. On the other hand, from being parties at war to being 'partners in progress', US and Vietnam have come a long way. Since normalization of ties in 1995, the two countries have advanced their political, economic, diplomatic and cultural relations which have brought them closer together. For the US, Vietnam today forms an important part of the 'strategic rebalance towards Asia' which has been manifested with the establishment of the US-Vietnam Comprehensive Partnership in 2013. From cooperation in economy and trade to security and defence, Vietnam and the US have expanded their cooperation towards regional and global challenges as well. The paper seeks to draw a brief sketch of the current state of India-Vietnam relationship and looks at the cooperation in strategic areas which bring these two countries closer together. It tries to examine the role of the US in India-Vietnam relationship and assesses the extent to which shared concerns over US drive cooperation between the two countries. An attempt has also been made to analyze the US's recognition and enhanced understanding of the significance of the strategic environment in the Asia-Pacific and its necessity to link national interests with the political and economic order in the region. This would simultaneously lead to the understanding of the implications of Asia's rising power for US strategy.

\section{INDIA-VIETNAM RELATIONS}

The relationship between India and Vietnam are a product of historical understanding. It was established upon the shared values of decolonization and nationalism. India had been a benevolent supporter of Vietnam during the US intervention in the country. It had raised its concerns at the bombings during the Vietnam War (1954-1975), urging for resolution of the Vietnam conflict within the framework of the Geneva accords. In the aftermath of the unification of Vietnam, India extended her support in the reconstruction of economy and agriculture of Vietnam. Aid and assistance in the form of training of Vietnamese farmers, technical support to raise agricultural production and laying down of railway tracks were provided. The establishment of diplomatic relations between the two countries in 1972 signified the beginning of a relationship which came to be founded on common economic, trade, defence and security requirements. Regular bilateral visits of leaders of both sides contributed to an environment of trust and understanding between the two countries. It was on this basis of a strong political commitment which brought India and Vietnam closer to each 
other in the post-cold war period. The end of the cold war and the opening up of the economies infused new energy into the realm of bilateral relationship as new avenues for cooperation opened up. India-Vietnam trade increased from 50 million dollars in 1991 to nearly 817 million dollars in 2005-06 [1]. India's Look East Policy introduced in 1991 emphasised the importance of regional economic integration in which Vietnam was identified as a crucial pillar. During this time, the Association of Southeast Asian Nations (ASEAN), of which Vietnam became a member in 1995, was identified as a 'pivotal partner' for India in the Asia-Pacific region. Bilateral trade between India and Vietnam rose markedly, from 100 million dollars in 1996 to 1000 million dollars in 2006, though even at that stage the share of Vietnam's export to India still remained below 20\% [2].

The 2007 Strategic Partnership signed between the two countries was another milestone in the trajectory of the relationship as it sought to "diversify and deepen the relationship between India and Vietnam in a rapidly changing environment" [3]. Amidst the rising importance of the Asia-Pacific region, India and Vietnam have several motivations and areas on which they can work together. The common threats and challenges that these two countries face, their role in the multilateral fora, unique strengths, resources and capabilities have created a common space for them to collaborate in the Asia-Pacific century.

\section{STRENGTHENING TIES: INDIA-VIETNAM IN THE ASIA-PACIFIC CENTURY}

As strategic partners, India and Vietnam have developed a politico-diplomatic tradition based on convergence of interests and expediency. Their mutual interests range from political, economic, trade, investment and defence to cooperation in the field of energy, science and technology and education. Since the beginning of the twenty first century, the two countries have sought o deepen their cooperation by establishing regional consensus. Vietnam has shown its support to India's aspiration to deepen her ties with the ASEAN and has even recognized India's desire to seek summit partnerships, in the ASEAN Regional Forum (ARF), East Asian Summit (EAS) and the Asia Pacific Economic Cooperation (APEC). India and Vietnam are also members of the six-member Mekong-Ganga Cooperation (MGC) in which existing gaps like infrastructure loopholes, issue of mutual recognition of standards and border facilitation of trade need to be addressed.

Both Vietnam and India are fast emerging economies in the Asia-Pacific region and as such they have several opportunities to re-engage in strengthening their economic partnership. Expansion of the bilateral export basket, developing direct and frequent connectivity, enhancing competitiveness, working for easing visa regulations for business individuals and increase in mutual investments can create a conducive environment for realising profits for both sides. Vietnam's export-oriented economy has derived benefits by being a source of Foreign Direct Investment (FDI) in the sectors like mineral exploration and processing, sugar manufacturing, agro-chemicals, IT, and agricultural processing. India can find many opportunities for investment in several other areas like infrastructure projects, manufacturing of high-tech products, education and training. Defence and security ties are one of the major factors drawing the two countries together. India and Vietnam have been involved together in exchange of people for conducting surveys, exchanging experiences in building up forces, educating high-level personnel, training, logistics and engineering, organization of staff and equipment, production, repair and boosting quality of arms and technical equipments. Both the countries have more motivations for seeking improved ties with each other. An exchange of innovative technologies for manufacturing weapons, developing signals intelligence and imaging, conducting joint military exercises, promoting intelligence sharing to counter common threats, collaborating on cyber defense and increasing surveillance and reconnaissance capabilities are some other areas on which India and Vietnam can converge for deepening defence ties. Another important direction of the India-Vietnam cooperation is the shared concerns over the South China Sea. India and Vietnam can come closer to overcome the anxiety about China's territorial expansion in the South China Sea (SCS). In fact, the SCS has found significant place in the diplomatic agenda of India. It has especially received added significance under the Modi government's Act East Policy. In a Joint Communique between the Socialist Republic of Vietnam and the Republic of India released on the occasion of President Mukherjee's visit to Vietnam on September 2014, the two leaders had emphasized the direction of action as regards maintaining peace and stability in Asia with regard to the disputed waters of the SCS. They agreed on the necessity of freedom of navigation in the Sea and called the parties concerned to resolve disputes through peaceful means in accordance with universally recognized principles of international law, including the UNCLOS-1982 [4]. The changing geopolitical situation, slowdown in the global economy and the constant interplay of new forces have increased the scope for establishing synergy between India and Vietnam. Both the countries need to leverage its key resources ensuring sustainable mutual development and work on the untapped potentials and unrealized gains. 


\section{BACKGROUND OF US-VIETNAM RELATIONS}

From enemies at war to partners in progress, Vietnam's relationship with the US has made considerable strides in advancing political defence relations. However, the development of relations since normalization of diplomatic ties in 1995 owes much to a long history of mistrust between them. Perceiving the Vietminh, an organisation encompassing nationalists, socialists, peasant, student and other organisations, as a threat to the West, the US formulated a new foreign policy to contain the spread of communism known as the Truman Doctrine, after President Harry Truman on March 27, 1947. When France was slowly losing its hold over the Vietminh in the Franco-Vietminh war, the US signed an agreement with France to provide military aid to the French Associated States of Vietnam. However, the French finally had to surrender Dien Bien Phu and a series of agreements known as the Geneva Accords was declared on July 19, 1954, putting an end to the FrancoVietminh War. American involvement in Vietnam was again intensified by John F. Kennedy who increased US aid and expanded the role of American military personnel to combat growing insurgency in the south. The United States followed the policy of attrition throughout the 1960s, conducting bombing campaigns against North Vietnam. Facing domestic pressure with regard to increasing war expenditure, President Lyndon B. Johnson assured the masses that he would decrease American involvement in Vietnam and halt the bombing campaigns in North Vietnam. In May 1968, formal peace negotiations between the United States and the Democratic Republic of Vietnam began in Paris, France. Richard Nixon, who became the next President of the US, announced a plan to expedite American withdrawal from Vietnam.

The Nixon Doctrine in 1969, as it came to be known, marked a major departure in American foreign policy as far as Southeast Asia was concerned. The key principle of the doctrine proclaiming that United States would call on its allies and friends to supply their own manpower to defend themselves against communist expansion, also implied that the country would refrain from engaging in war in the Southeast Asian region.

This brings us to the question as to why major powers seek emerging powers and why did US in particular feel the need to engage Vietnam after a violent war. There have been many wars in the past between countries which had ingrained scars so deep in the minds of people, that it became impossible for establishment of normalization of relations. On the other hand, there have also been wars between parties who soon realised the futility of soured relationships which if normalized and upgraded for the sake of mutual benefits can accrue significant advancements in development. The US was not ignorant of the prospects that Vietnam as a logistics centre of Asia offered. With a 3,200 km long coastline and the presence of 114 seaports, out of which 14 are relatively large and capable of becoming the platform for development, Vietnam offered tremendous potential to the US market. For Vietnam, financial aid was the prime requirement to recover from the devastations caused by the war. Apart from that, Vietnam also required access to the global market and strengthening defence capacities, which the US could offer. However, US officials noted that progress towards normal relations depended on Vietnam fully cooperating in obtaining the fullest possible accounting for U.S. personnel listed as prisoners of war/missing in action (POW/MIAs).

\section{NORMALIZATION OF RELATIONS}

US-Vietnam relations essentially remained frozen after 1975. Following North Vietnam's victory in 1975 over US ally South Vietnam, the US maintained a trade embargo, suspending foreign assistance to Vietnam. It was after a substantial period, to be precise only during the 1990s, that the relationship started to normalize. In 1991 the United States established an office in Hanoi to address the issue of American servicemen missing since the war. In an act of showing acknowledgement after Vietnam demonstrated cooperation in the search for evidence of the 2,238 Americans officially listed as 'missing' in the war, Bill Clinton, the then American President lifted the 19-year old trade embargo, tossing away a vital reminder of America's most divisive wars. The lifting of the embargo signalled the opening of America's doors to one of the fastest growing economies in Southeast Asia. In 1992, the United States provided 3 million dollars of humanitarian aid (mainly prosthetics and aid to abandoned or orphaned children) for Vietnam; restored direct telecommunications with Vietnam; allowed U.S. commercial sales to meet basic human needs in Vietnam; and lifted restrictions on projects carried out in Vietnam by U.S. nongovernmental organizations [5].

Despite the lifting of the embargo, Vietnamese exports remained subject to high tariffs pending the communist-led country's qualification as a 'most favoured nation'. It was in July 1995 that the US established full diplomatic relations with Vietnam. Clinton's announcement of 'normalization of relations' in 1995 marked a milestone in US-Vietnam relations. In November 2000, Clinton became the first President to visit Vietnam since Richard Nixon's 1969 trip to South Vietnam during the Vietnam War.

Meanwhile, the Doi Moi reforms in 1986 ushered a new dawn for the Vietnamese economy as the country opened its doors to the world's developed economies, including USA. The final step toward full economic normalization between the United States and Vietnam was accomplished in December 2006, when President Bush extended Permanent Normal Trade Relations (PNTR) status to Vietnam. This in turn helped Vietnam to get access to the World Trade Organization (WTO) in 2007. Membership to the WTO demands 
commitment of its members towards fundamental principles in trade like Most Favoured Nation treatment (MFN), transparency, lowering trade barriers to negotiations and reliance on tariffs. The US decision to grant PNTR status was taken in the right direction as it helped to fulfil the preconditions for WTO accession.

\section{DEVELOPMENT OF RELATIONS}

The PNTR status granted to Vietnam led to development of economic and trade relations between the two countries as the volume of bilateral trade rose from 450 million dollars in 1995 to nearly 35 billion dollars in 2014 [6]. In the same year, the US administration lifted the 'Country of Particular Concern' (CPC) status which had been given to Vietnam by the State Department's International Religious Freedom Report in 2004 for the prevailing condition in the field of human rights. Because of many positive steps taken by the Vietnamese government since 2004, the US struck off Vietnam from the list of CPC. The State Department in November 2006 announced that with a decline in cases of forced renunciations of faith, release of religious prisoners and expansion of religious freedom, the situation had considerably improved in Vietnam.

US engagement in Vietnam has also been necessitated by the legacy issues such as Unexploded Ordnance (UXO)/demining, Missing in Action (MIA) accounting, and Agent Orange (a defoliant used by U.S. forces) providing the foundations for the U.S.-Vietnam defence relationship. Besides, mutual interest in addressing the challenges of humanitarian assistance/disaster relief, search and rescue, and maritime security have allowed the defence relationship to upgrade, with Vietnam participating in U.S.-provided capacity-building training in these areas.

Today, the United States is committed to helping Vietnam continue on its path of economic reforms, including efforts required to fully implement its commitments under the Trans Pacific Partnership (TPP) through technical assistance [7]. The US and Vietnam can also explore closer ties on the issue of the South China Sea (SCS), where China for the most part claims a major chunk of the SCS. Though the Chinese President Xi Jinping in recent times has said that common interests between China and Vietnam far outweigh differences, yet at the same time, China also maintains that the vexed issue involved both issues of sovereignty and maritime rights as well as 'national feelings' [8]. US, meanwhile has pronounced that it will continue to support freedom of navigation operations on the sea, simultaneously advocating a peaceful settlement of disputes in the region. During President Barrack Obama's visit to Vietnam in May 2016, both the countries agreed to elevate mutual security. On SCS, the President remarked that, "In the South China Sea, the United States is not a claimant in current disputes. As we go forward, the United States will continue to fly, sail and operate wherever international law allows, and we will support the right of all countries to do the same" [9]. Vietnam supports peaceful resolution of disputes as well, nevertheless it also reasserts its own sovereignty claims.

\section{IMPORTANCE OF INDIA AND THE ASIA-PACIFIC FOR THE US}

Economic liberalisation in the post-cold war period redefined the economies of Asian countries like India, where the New Economic Policy stressed on an open door policy. India's economic performance in the post-reforms period had been remarkably substantial. The average growth rate in the ten year period from 199293 to 2001-02 was around 6.0 percent, which put India among the fastest growing developing countries in the 1990s [10]. Meanwhile, with the emphasis on 'Look East Policy' and ASEAN in the 1990s, India-Vietnam relations saw an upward trajectory. Bilateral trade grew rapidly between the two countries from 72 million dollars in 1995 to more than 1 billion dollars in 2006 [11]. The US had been positively tracking all these developments in the Asian region and it became clear that it must take into account changing dynamics in the Asia-pacific region - especially in economics and security. It was in the recognition of these opportunities that the US desired to pursue access to the larger Asian market. India's rise in the $21^{\text {st }}$ century as an emerging power led to an increasing Indo-US engagement in many dimensions, mainly in the fields of economic, scientific and technological co-operations, strategic and diplomatic collaborations which opened avenues for establishing trust on a number of areas like high-technology trade, civil nuclear cooperation, space, and missile defense. India was hailed by the US 'as a global power in the $21^{\text {st }}$ century' and also as an 'increasingly important partner for the United States' [12].

The US's strategy of 'pivot' towards the Asia-Pacific complemented India's geopolitical influence in the region. One of the most vital aspects of the 'rebalance' is the use of multilateral forums to advance broader regional goals. The US has actively engaged in fostering multilateralism through the Asia-Pacific Economic Cooperation (APEC) by creation of opportunities for prosperity throughout the US and the Asia-Pacific region with the help of free and open trade and investment. In this connection, the US priority is to enhance regional integration and stability, while establishing systems conducive to US economic competitiveness [13]. It is worthy to be mentioned that open trade and investment in the region has been one of the priority initiatives for the US which has yielded good results. In 2013, US goods and services trade with APEC countries totalled 2.9 trillion dollars and the country had a service trade surplus of 123.7 billion dollars with APEC countries in the 
same year, up from 5.1 per cent in 2012 [14]. As one of the most promising markets and growth drivers in the wider Asia-Pacific, India can contribute towards greater regional cooperation and prosperity. In fact, the US has welcomed India's interest in joining the APEC. The US in this regard can leverage the significant and growing capabilities of both India and Vietnam to build a network that sustains and strengthens regional development and addresses regional and global order. As members in the East Asia Summit (EAS), India and Vietnam can use the platform for holding dialogues on maritime security, terrorism and economic and socio-cultural cooperation with the US. At the EAS and the ASEAN Summits in 2015, the US had directly addressed the maritime disputes in the South China Sea and had encouraged the relevant countries in the region to take steps to address disputes peacefully and in accordance with international law. In the recent past, New Delhi and Washington have been calling for freedom of passage in the international waters, much to the discomfort of Beijing. Meanwhile, in the last few years, Vietnam's diplomatic profile has grown in India and US's strategic calculus. While both India and the US are not claimants to the South China Sea dispute, their engagement shows a mutual desire for maritime cooperation in the region. The US has demonstrated its commitment to support the maritime capabilities of Southeast Asian countries, including Philippines, Vietnam, Indonesia and Malaysia by providing 250 million dollars from across the US government. This assistance, as it claims, will also help their partners develop the necessary infrastructure and logistical support, strengthen their institutions and enhance their practical skills to develop sustainable and capable maritime forces [15]. A more assertive stand on the South China Sea by Beijing has led to US upping its military presence in the Sea. Furthermore, the ongoing dispute has intensified closer regional cooperation of countries with Japan offering military aid to countries such as Philippines and Vietnam. India has also demonstrated her clear stand on the issue supporting Hanoi's claims and accepting the Vietnamese invitation to explore oil and gas in blocks 127 and 128, in the process inviting resentment from Beijing. The common interests of the three countries -US, India and Vietnam in isolating China have drawn them closer to each other.

The above simply highlights the fact that the US has stated its active presence, evinced its keen interests and articulated its agenda in the Asia-Pacific region quite distinctly. It has also become an important element to further economic cooperation between India and Vietnam. For instance, in the US-led TPP, India has indicated that it will seriously consider the opportunities to invest in Vietnam for export to the other TPP member countries [16]. The Indian government has already launched a preferential credit package worth 300 million dollars for investments in the garment and textile sector of Vietnam over ten years using Indian equipments, according to the Vietnam Textile and Apparel Association (VITAS) [17]. In this connection, India's participation in the comprehensive Free Trade Area of the Asia Pacific (FTAAP) or joining an expanded TPP can usher in huge export gains of more than 500 billion dollars a year [18]. India can hence benefit from indirect participation in the TPP, however the implementation of the agreement currently hangs in doubt due to the vehement opposition expressed by President-elect Donald Trump, as he is of the opinion that it is harmful for US economic interests. Nonetheless, only future developments would be able to determine whether India and Vietnam can actually gain benefits from the TPP or whether attention would be diverted towards other multilateral regimes through which India and Vietnam can gain mutually.

Today, in the Asia-Pacific century, India and Vietnam, as emerging economies share significant growth rate. "Vietnam's per capita GDP growth since 1990 has been among the fastest in the world, averaging 5.5 per cent a year since 1990, and 6.4 per cent per year in the 2000s [19]." Vietnam's economy in 2015 grew at its fastest pace in five years, official figures at the General Statistics Office had stated [20]. On the other hand, the Indian economy, according to the World Bank is the world's fourth largest economy whose "recent growth and development has been one of the most significant achievements of our times" [21]. India's growth at 7.6 per cent in 2015-16 is the fastest in five years [22]. The changing economic dynamics within the Asia-Pacific region has presented many opportunities for enhancing India-Vietnam economic cooperation. This also presents both the countries with an opportune moment to avail alternatives to Chinese manufacturing.

At the same time, this could be a favourable and opportune moment for the US to seize as well. For the US, the sectors which are of substantial importance in case of both the countries and out of which the US can derive advantages are energy (renewable and non-renewable), defence, pharmaceuticals, low cost manufacturing and services. By forging cooperative ties in the field of R \& D for instance on discovery of cost-effective sustainable practices and exploring clean energy solutions and smart grid technologies, not only the US, but India-Vietnam as collaborative partners can also derive immense benefits in the form of exchange of best practices and experiences.

\section{CONCLUSION}

The US today recognises that no other region holds more potential for growth, development and prosperity than the Asia-Pacific region [23]. The US welcomes India's active role in Asia's regional institutions which strengthens regional order. Along with India's growing defence capabilities, coupled with a shared recognition of the importance of the freedom of navigation in the Indian Ocean, the US today finds India to be 
part of its 'most important democratic partners' [24]. On the other hand, US relations with Vietnam have become increasingly cooperative and comprehensive, guided by the 2013 US-Vietnam Comprehensive Partnership. For the US, the fullest possible accounting of Americans missing and unaccounted for remains a high priority and with the collaboration of the Vietnamese counterparts, recovery missions are regularly held since August 2011. The US has also expressed commitment towards addressing legacy issues such as UXO/demining, MIA accounting and Agent Orange which together with the US-Vietnam Joint Vision Statement on Defence Relations signed in 2015 has warmed and upgraded defence ties between the two countries [25]. Inclined to take the best out of regional collaboration and at the same time for promoting regional peace and prosperity, the US can commit to a future where effective security and development are founded on recognized mutual security, international law and international standards. The U.S. can reappraise the symbiotic multifaceted relations between India and Vietnam so as to work together to build an order of regional peace and stability.

India and Vietnam both have several mutual areas of concern and interests, however, the US can play an important factor helping to shape India-Vietnam bilateral relations. A more engaged US, who shares friendly relations with both India and Vietnam, will lead to a stable balance of power in the Asia-Pacific region, which in turn can act as an equilibrium in the face of a rising China. Charting a course for the future of India-Vietnam relationship, the US can very well be a positive factor in advancing the relationship between the two countries in view of the strategic rationale of close ties with both of them.

\section{REFERENCES}

[1] Vietnam eyes joint ventures with Indian businesses", Vietnam Breaking News, September 10, 2006, https://m.vietnambreakingnews.com/2006/09/vietnam-eyes-joint-ventures-with-indian-businesses/ accessed on December 8, 2016.

[2] Shantanu Shrivastava, Four Decades of India-Vietnam Economic and Commercial Relations and the Way Forward in Rajiv K. Bhatia, Vijay Sakhuja and Vikash Ranjan (Ed.) India Vietnam: Agenda for Strengthening Partnership (New Delhi: Shipra Publications, 2013) 33-42.

[3] "Agreements signed during the State Visit of the Prime Minister of Vietnam to India", Ministry of External Affairs, Government of India, July 6, 2007 http://www.mea.gov.in/pressreleases.htm?dtl/2537/Agreements+signed+during+the+State+Visit+of+the+Prime+Minister+of+Vietna m+to+India accessed on July 5, 2016.

[4] Joint Communique between the Socialist Republic of Vietnam and the Republic of India, Hanoi, Vietnam, 15 September, 2004, http://www.presidentofindia.nic.in/press-release-detail.htm?1105 accessed on 13 July, 2016.

[5] Mark E. Manyin, "US-Vietnam Relations: Background and Issues for Congress", CRS Report for Congress, October 31, 2008, https://www.fas.org/sgp/crs/row/RL33316.pdf accessed on September 14, 2016, 8.

[6] US Relations with Vietnam", Bureau of East Asian and Pacific Affairs, US Department of State, February 11, 2015, http://www.state.gov/r/pa/ei/bgn/4130.htm accessed on September 8, 2016.

[7] Fact Sheet: United States-Vietnam Relations", The White House, Office of the Press Secretary, May 23, 2016, https://www.whitehouse.gov/the-press-office/2016/05/23/fact-sheet-united-states-vietnam-relations accessed on September 8, 2016.

[8] [China says interests outweigh differences with Vietnam", Reuters, September 13, 2016, http://www.reuters.com/article/us-china-vietnam-idUSKCN11J00X accessed on September 14, 2016.

[9] Remarks by President Obama in Address to the People of Vietnam", The White House, Office of the Press Secretary, May 24, 2016, https://www.whitehouse.gov/the-press-office/2016/05/24/remarkspresident-obama-address-people-vietnam accessed September 16, 2016.

[10] M.S. Ahluwalia, Economic Reforms in India Since 1991: Has Gradualism Worked?, Journal of Economic Perspectives, 16 (3), 2002, 67-88.

[11] Nguyen Huy Hoang, Exploring Areas of Cooperation in Vietnam-India Economic Relations in the Context of ASEAN-India Free Trade Agreement in Vijay Sakhuja (Ed.) India-Vietnam Strategic Partnership: Exploring Vistas for Expanding Cooperation (New Delhi: Pentagon Press, 2011) 19.

[12] Reaching New Heights: US-India Relations in the $21^{\text {st }}$ century", 2005, https://newdelhi.usembassy.gov/uploads/images/jjDVelFXR3rAB0Of5Ke7dg/reach.pdf accessed on September 8, 2016.

[13] US Strategic Interests and the APEC and East Asia Summits", US Department of State, December 2 , 2015, https://www.state.gov/p/eap/rls/rm/2015/12/250315.htm accessed on December 26, 2016.

[14] “US-APEC Trade Facts", Office of the United States Trade Representative, n.d., https://ustr.gov/tradeagreements/other-initiatives/asia-pacific-economic-cooperation-apec/us-apec-trade-facts\# accessed on September 8, 2016.Op. Cit. No. 11. 
[15] India jumps on the TPP bandwagon in Vietnam", Tuoi Tre News, July 21, 2015, http://tuoitrenews.vn/business/29349/tpp-train-too-attractive-for-vietnam-to-miss accessed on July 14, 2016.Ibid.

[16] "Economic Survey 2015-16 - External Sector", n.d., http://indiabudget.nic.in/es2015-16/echapvol204.pdf accessed on July 14, 2016.

[17] Vietnam: Overview", The World Bank, April 11, 2016, http://www.worldbank.org/en/country/vietnam/overview accessed on July 6, 2016.

Vietnam's economy grows at highest in five years", The Japan Times, December 26, 2012, http://www.japantimes.co.jp/news/2015/12/26/business/vietnams-economy-grows-at-highest-rate-in-fiveyears/\#.V9JmX_194dU accessed September 9, 2016.

[18] India: Overview", The World Bank, n.d., http://www.worldbank.org/en/country/india/overview accessed on July 6, 2016.

[19] India's growth at 7.6 per cent in 2015-16 fastest in five years", The Economic Times, May 31, 2016, http://economictimes.indiatimes.com/news/economy/indicators/indias-growth-at-7-6-in-2015-16-fastestin-five-years/articleshow/52522153.cms accessed on September 9, 2016.

[20] Gottenmoeller, Rose, "The Role of the United States in the Asia-Pacific Security", US Department of State, March 6, 2015, http://www.state.gov/t/us/2015/239922.htm accessed September 19, 2016.Ibid.

[21] US Relations with Vietnam", Bureau of East Asian and Pacific Affairs, US Department of State, Fact Sheet, August 25, 2016, http://www.state.gov/r/pa/ei/bgn/4130.htm 